\title{
Feed and Bleed Bipolar Membrane Electrodialysis Process
}

\author{
Med Amine Rachid Ben Ali ${ }^{1, *}$ and Wessam N. El-Sayed ${ }^{2}$ \\ ${ }^{1}$ Department of Applied Chemistry and Chemistry Technology, College of Sciences and Arts \\ Alkamil - University of Jeddah - KSA \\ ${ }^{2}$ Chemistry Department, Faculty of Science, Suez University, Egypt
}

\begin{abstract}
In this study, a bipolar membrane electrodialysis process (BPMED) is applied to regenerate nitric acid and ammonia by splitting ammonium nitrate. Firstly, we have proved the process feasibility in batch mode. Secondly, using the same operating conditions, we have proposed to extend the study to a continuous (feed and bleed) operating mode. Forecast calculations, derived from the balance material equations, and using the batch mode results, allowed the estimation of the continuous functioning parameters for both acid and salt. There is a good agreement between the performances of the two functioning modes. The acid and ammonia current efficiencies reached respectively 85 and $83 \%$ in batch processing, and 83 and $80 \%$ in continuous processing.
\end{abstract}

\section{Introduction}

The nuclear fuel processing industry generates large volumes of wastewaters containing ammonium nitrate. These wastewaters are produced during the conversion of uranyl nitrate to uranium oxide. Thus, ammonium nitrate is produced at a concentration around 1 or $2 \mathrm{~mol} \mathrm{~L}^{-1}$. Due to the presence of traces of uranium, ammonium nitrate solutions are not suitable for use in agriculture fertilizer production. For economic and environmental reasons, splitting of ammonium nitrate to ammonia and nitric acid is advantageous. Membrane electrolysis ${ }^{1-3}$ and bipolar membrane electrodialysis (BPMED) ${ }^{4-6}$ were used to treat solutions containing ammonium nitrate. BPMED has been investigated in many studies ${ }^{7-10}$. The principle of this operation lies in the use of a bipolar membrane where water splitting to $\mathrm{H}^{+}$and $\mathrm{OH}^{-}$is performed. The bipolar membrane is associated to homopolar ion-exchange membranes to produce acid and base from a salt. Figure 1 illustrates the principle of the operation. A three-compartment cell is used. The bipolar membrane is associated to an anionexchange membrane and a cation-exchange membrane. The salt solution containing $\mathrm{NH}_{4} \mathrm{NO}_{3}$ is fed to the central compartment between the two homopolar membranes. Nitrate ion $\mathrm{NO}_{3}{ }^{-}$migrates through the anion-exchange membrane and enters the acid compartment to generate nitric acid with proton produced by the bipolar membrane. On the other side, ammonium ion $\mathrm{NH}_{4}{ }^{+}$migrates through the cationexchange membrane to the base compartment to generate ammonia with hydroxide ion produced by the bipolar membrane.

Other authors 4,11 studied the splitting of ammonium nitrate solutions by BPMED in order to regenerate nitric acid and ammonia. The authors concluded that this technique was not suitable for direct treatment of ammonium nitrate waters due to the low current efficiency linked to ammonia production.

They proposed to operate in two steps. First, addition of sodium hydroxide to salt solution and stripping of ammonia and, in a second step, the sodium nitrate solution obtained is treated by BPMED to regenerate nitric acid and sodium hydroxide. In this work, direct treatment of ammonium nitrate is carried out by coupling bipolar membrane electrodialysis and continuous in situ stripping of ammonia. Selection of homopolar ion-exchange membranes to use with the bipolar membrane was achieved. Then, with the selected membranes, the production of nitric acid and ammonia was studied. These productions were carried in batch and continuous mode. 


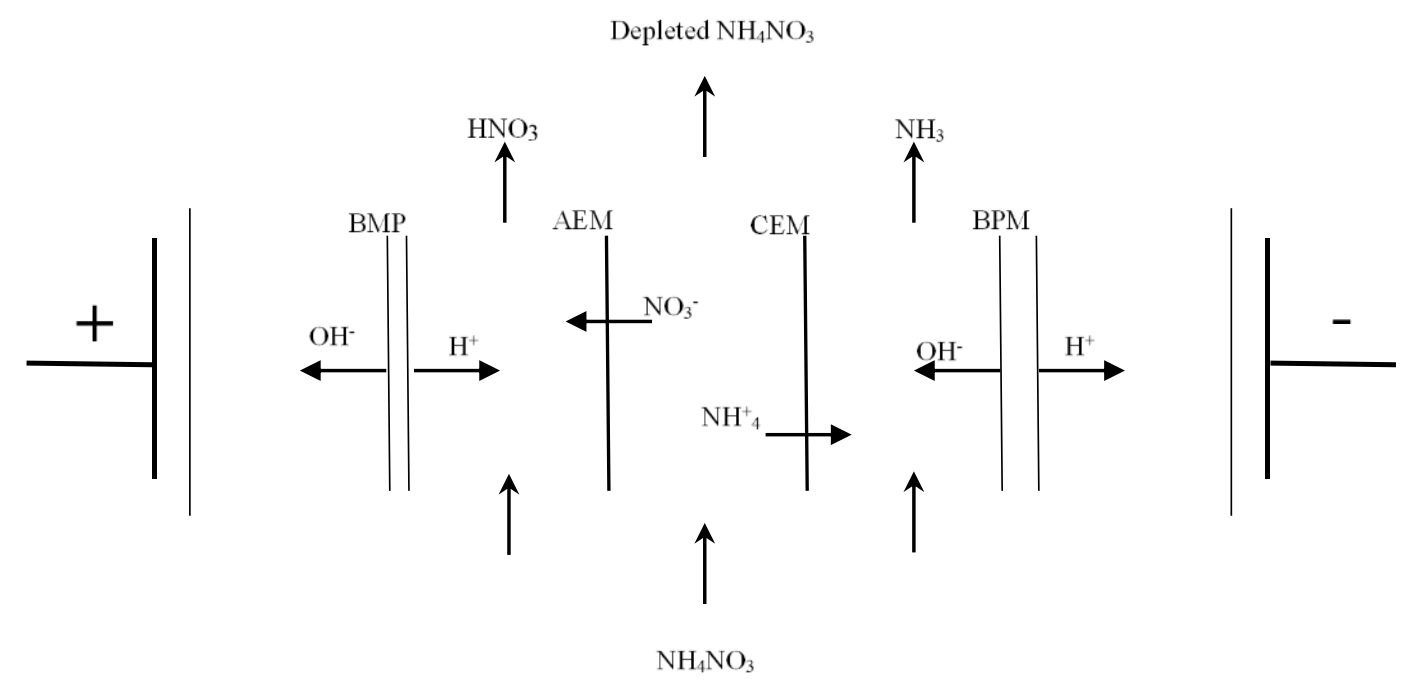

Figure 1. Principle of ammonium nitrate splitting by bipolar membrane electrodialysis.

\section{Experimental details}

\section{Ion-exchange membranes}

The membranes used are listed below:

- Bipolar membrane: BP1 (Tokuyama Soda).

- Cation-exchange membrane: CMB (Tokuyama Soda), Nafion 117 (Dupont de Nemours), CRA (Solvay).

- Anion-exchange membrane: AW (Solvay) ${ }^{12}$, ACM (Tokuyama Soda), AAV (Asahi Glass).

\section{The electrochemical cell stack}

The cell stack supplied by Eurodia Industrie (Wissous, France) was used with four cells. Active area was $200 \mathrm{~cm}^{2}$ per cell. Solutions were pumped through the cell compartments continuously from recirculation tanks. The compartment width was about $0.8 \mathrm{~mm}$ and the flow rate was about $20 \mathrm{~L} \mathrm{~h}^{-1}$ per cell (liquid velocity $\sim 6 \mathrm{cms}^{-1}$ ). Manometers placed at the cell inlet of each circuit provided information required to properly control the working pressure. The adjustment of pressure in the different compartments to the same value was achieved by varying the flow rate of solutions and by means of the pressure valve in the base circuit (Fig. 2).

\section{Operating conditions}

Relatively high solution conductivity is required to operate at the usual current densities under reasonable voltage. Referring to Figure 1, the base circuit is free of ions and presents a small conductivity. In order to enhance the conductivity, sodium hydroxide was added. No separation problem is induced. Moreover, ammonia stripping is more efficient in alkaline conditions.

The experiments were achieved under the following conditions named "standard conditions", otherwise any nonstandard parameter is specified:
- Acid circuit: nitric acid $\approx 1 \mathrm{~mol} \mathrm{~L}^{-1}$ (membranes should not withstand strongly acidic media)

- Salt solution: $\mathrm{NH}_{4} \mathrm{NO}_{3} 2 \mathrm{~mol} \mathrm{~L}^{-1}$

- Base circuit: $\mathrm{NH}_{3}$ and $\mathrm{NaOH} 1$ mol L $\mathrm{L}^{-1}$ each (the ammonia concentration in the base circuit is equal to the equilibrium value in the stripping conditions, for example $\left[\mathrm{NH}_{3}\right]=1 \mathrm{~mol} \mathrm{~L}^{-1}$ for $14.5 \mathrm{kPa}, 45{ }^{\circ} \mathrm{C}$ and $\left.[\mathrm{NaOH}]=1 \mathrm{~mol} \mathrm{~L}^{-1}\right)$;

- The starting volume of each solution is about $2 \mathrm{~L}$; - The current density is held constant at $500 \mathrm{~A} \mathrm{~m}^{-2}$.

Batch operation and continuous feed and bleed operation were carried out. Acid and ammonia concentrations were determined by titration. Volume variations for each solution were determined by means of a measuring scale on the recirculation solution tank. Due to the limited chemical resistance of the bipolar membrane nitric acid concentration was kept lower than $3 \mathrm{~mol} \mathrm{~L}^{-1}$.

\section{Ammonia stripping}

During electrodialysis, produced ammonia was extracted continuously from the recirculation tank. This was achieved by exerting a reduced pressure (generally $14.5 \mathrm{kPa}$ unless other value specified) and by heating to $45{ }^{\circ} \mathrm{C}$ (the temperature must not exceed this value for thermal stability of the bipolar membrane). The temperature was controlled by circulation of thermostated water in the jacketed recirculation tank. During the tests, small variations of the temperature were observed (no more than 1 or $2 \circ$ C) ${ }^{13}$.

In our case, the extracted ammonia was absorbed in nitric acid in order to determine the produced quantity. Otherwise, ammonia must be absorbed in water to give ammonia solution. Figure 2 represents the ammonia stripping and absorption device. 


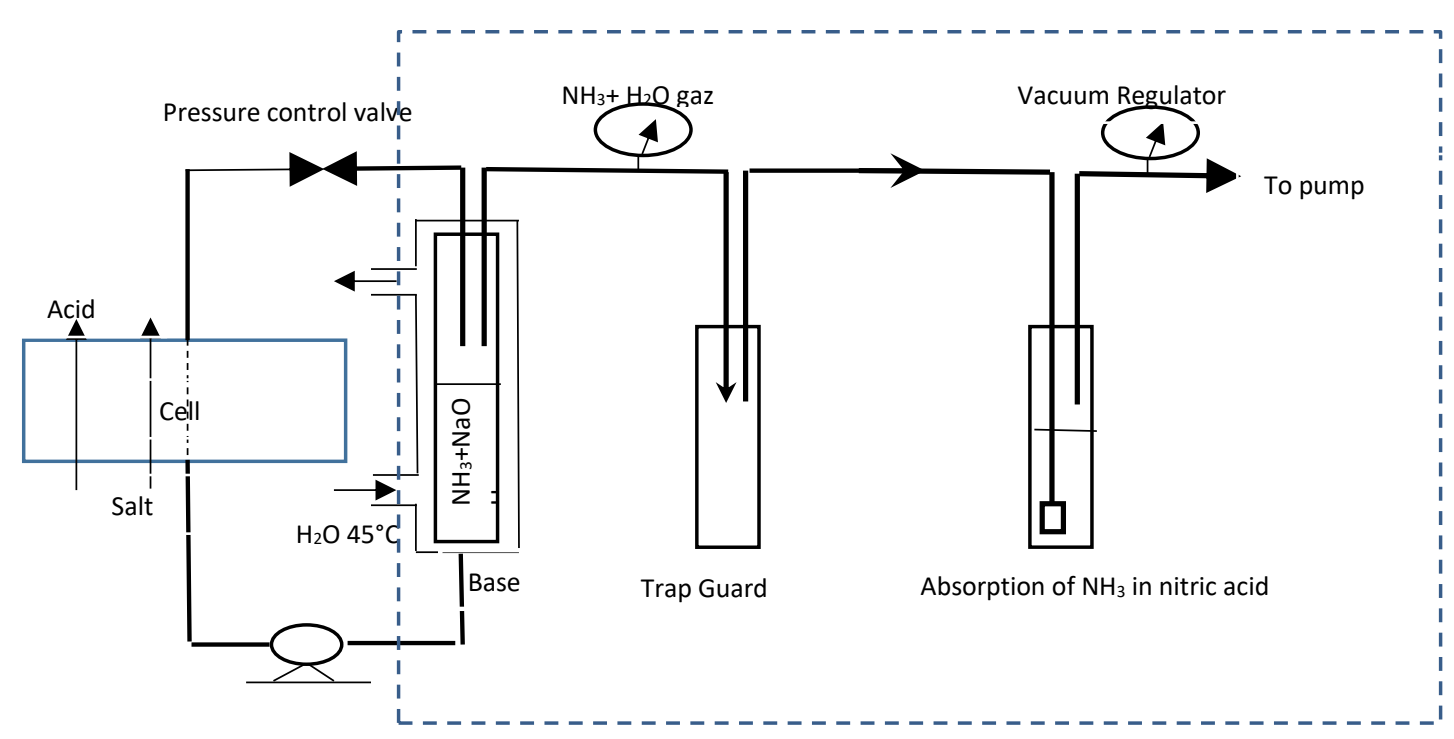

Reduced pressure zone

Figure 2. Ammonia stripping and absorption device (nitric acid is used here only for quantitative determination of ammonia).

\section{Batch mode results and discussion}

First, the production of nitric acid and ammonia was tested successfully. Then, selection of membranes was achieved and the effect of different parameters studied in batch mode.

\section{Nitric acid and ammonia production}

The current efficiency (\%) is a measure of the system's ability to use the current advisedly. The current efficiency $\mathrm{CE}(\%)$ for production of component $\mathrm{C}$ during a time $\Delta \mathrm{t}$ is the ratio between the moles of $\mathrm{C}$ produced during $\Delta \mathrm{t}$ and the theoretical moles corresponding to the quantity of charge involved during $\Delta \mathrm{t}$.

$C E=\frac{P}{P_{\text {theorical }}}=\frac{\Delta(C V)}{\frac{n J S \Delta(t)}{F}}$

$=\frac{\Delta(C V) F}{n J S \Delta(t)}$ (section Volume variations)

During a $2 \mathrm{~h}$ reaction where acid concentration increased from 1 to $2 \mathrm{~mol} \mathrm{~L}^{-1}$, the average CE for nitric acid is near $85 \%$. The average $\mathrm{CE}$ for ammonia production during this experiment is $83 \%$, a value close to that for acid if all the produced ammonia is simultaneously stripped from the base circuit.

\section{Effect of acid concentration}

The differential current efficiency (DCE) is given by the relation:

$D C E=\frac{d(V C) F}{J S d t}=\frac{(V d C+C d V) F}{J S d t}$

$V$ and $C$ are the volume and concentration of nitric acid solution, $J$ the current density, $S$ the membrane surface area and $F$ is the Faraday constant: 96485 As $\mathrm{mol}^{-1}$. The term $\mathrm{d} V / \mathrm{d} t$ is known (Section Volume variations) and the term $\mathrm{d} C / \mathrm{d} t$ is obtained from a 120 min experiment (the slope of the tangent to the curve at the considered point). The DCE varies with acid concentration as reported in Figure 3. The change in DCE is linear in the investigated range, dropping from $90 \%$ to $1 \mathrm{~mol} \mathrm{~L}^{-1}$ concentration to $77 \%$ for $2 \mathrm{~mol} \mathrm{~L}^{-1}$. The decrease of the DCE is explained by proton leakage through the anion-exchange membrane, which is greater when acid concentration increases ${ }^{14}$. 


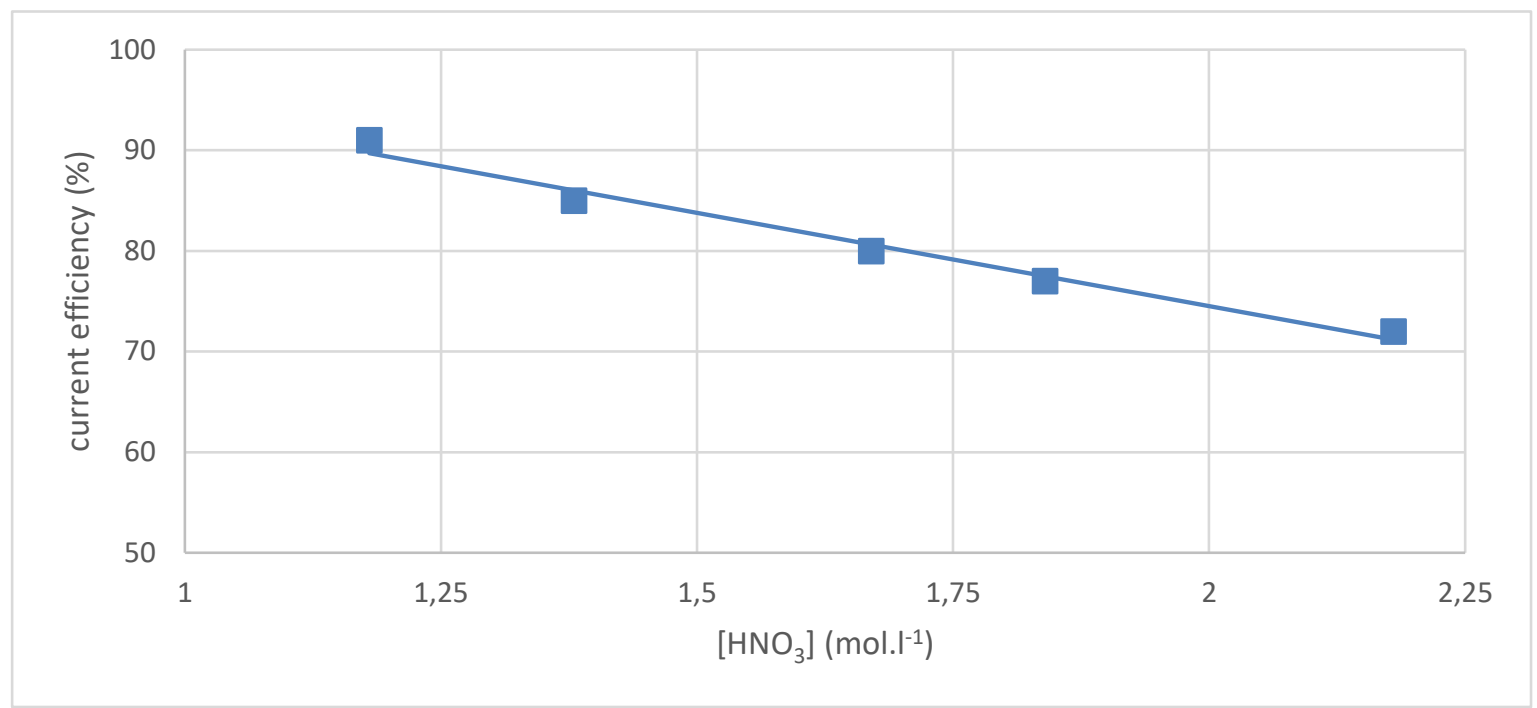

Figure 3. Nitric acid differential current efficiency vs. acid concentration

\section{Homopolar membranes selection}

The objective here is to select the pair of homopolar membranes which, in association with the bipolar membrane BP1, leads to the highest current efficiency.

\section{Anion-exchange membrane}

We have tested the three anion-exchange membranes (Section Ion-exchange membranes) together with the CMB membrane. These anionexchange membranes are known to have a small proton leakage and are suitable for working with acids.

Table 1. $\mathrm{HNO}_{3}$ and $\mathrm{NH}_{3} 120$ min average current efficiencies (CE, \%) for different pairs of anion and cationexchange membranes under our standard conditions.

\begin{tabular}{|l|c|c|c|c|c|}
\hline & AW-CMB & ACM-CMB & AAV-CMB & AW-N117 & AW-CRA \\
\hline $\mathrm{HNO}_{3}$ average CE (\%) & 83 & 61 & 52 & 81 & 79 \\
\hline $\mathrm{NH}_{3}$ average CE (\%) & 84 & 64 & 50 & 72 & 57 \\
\hline
\end{tabular}

Table 1 reports the acid and base average current efficiency for different sets of membranes in the standard conditions for a 120-min experiment. Final acid concentrations are respectively $2,1.7$ and $1.6 \mathrm{~mol}$ $\mathrm{L}^{-1}$, for AW, ACM and AAV membranes. Ammonia concentration in the base circuit remains constant at about $1 \mathrm{~mol} \mathrm{~L}^{-1}$. Under the experimental conditions, acid and ammonia current efficiencies are close for each set of membranes. The AW membrane exhibits the highest current efficiency value. This is probably linked to its small water content. This membrane was chosen for the remainder of this study ${ }^{15}$.

\section{Cation-exchange membrane}

The three cation-exchange membranes (Section Ion-exchange membranes) were each tested with the AW membrane.

The acid current efficiency is nearly the same for the three cation-exchange membranes tested. The cation-exchange membrane has only a small effect on the production of nitric acid. In contrast, the ammonia production is different with each cation-exchange membrane tested. The ammonia current efficiency varies from $84 \%$ for the CMB membrane to $57 \%$ for the CRA membrane. This is probably due to the ammonia diffusion through these membranes from the base compartment to the salt one. During these experiments, the $\mathrm{pH}$ of the salt solution decreased slightly with the CMB membrane but it increased significantly for the two-other cation-exchange membranes. Since the CMB membrane seems to prevent ammonia diffusion, the AW and CMB pair of membranes are used for all other experiments.

\section{Volume variations}

Volume variations occur during the mass transfer between the different solutions and must be taken into account to establish the material balance and accurately calculate current efficiencies.

Figures 4 and 5 illustrate both the evolution of acid compartment and salt compartment volumes according to time: 


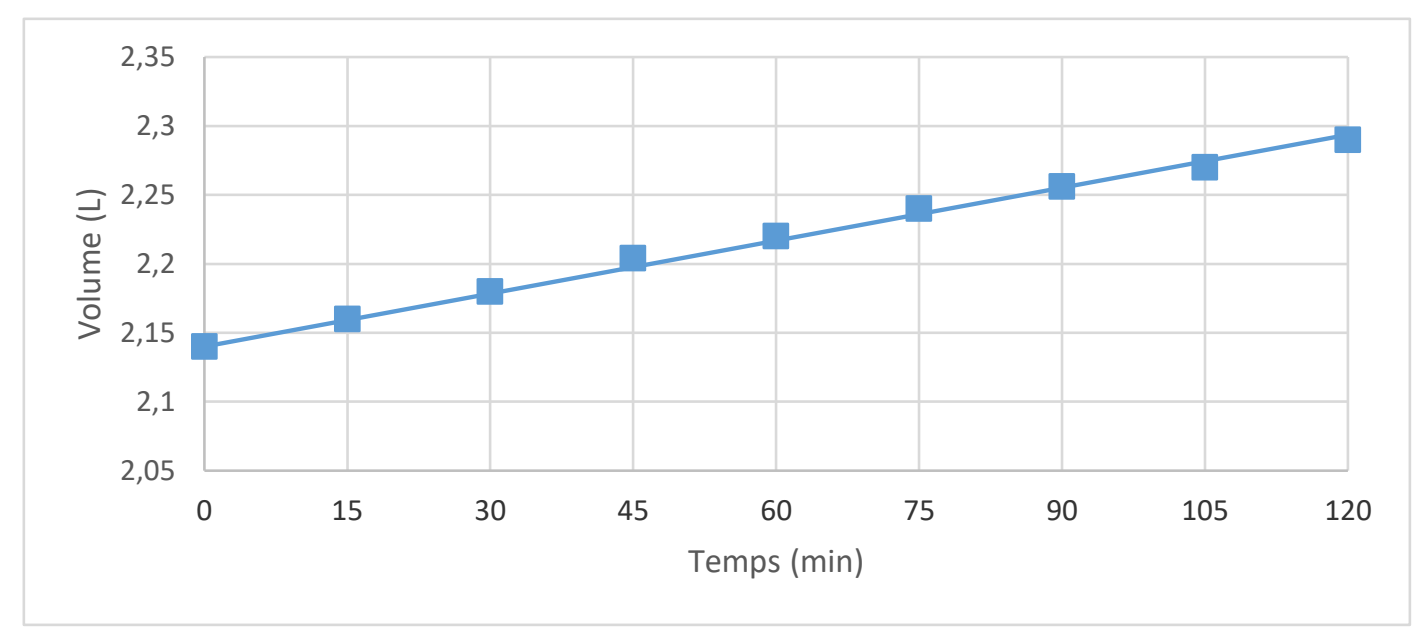

Figure 4: Evolution acid compartment volume versus time

The acid solution volume increases as the salt volume decreases. These changes are due to the transfer of solvated (water) ions through the membranes. The volume of base solution should also increase but due to water evaporation under the reduced pressure required for ammonia stripping it remains practically constant. The volume variation in the salt compartment is about $230 \mathrm{ml} \mathrm{h}^{-1}$, compared to the total variation in the acid and stripping compartments $\left(75+140=215 \mathrm{ml} \mathrm{h}^{-1}\right)^{16}$.

To confirm the electrodialysis results obtained in batch mode, we propose to study the electrodialysis in continuous mode (feed and bleed)

\section{Electrodialysis Study in continuous (feed and bleed) operating mode}

The objective of this study is to produce a nitric acid solution with constant flow rate and concentration, as well as gaseous ammonia with constant flow rate. Starting from any initial conditions, a steady-state was reached.

For continuous operation, a feed and bleed mode were utilized. An adjustable flow rate pump introduced pure water into the acid recirculation tank maintaining the desired acid concentration. Ammonium nitrate solution was similarly pumped into a salt recirculation tank. For the base circuit, the operation was performed in the same way than in batch mode taking into account that volume change in this circuit was negligible and that a quasi-stationary state was reached.

For acid and salt solution constant volume of the circuit was insured by an overflow. Their volume value was about $3 \mathrm{~L}$.

Figure 6 shows a diagram of the experimental device suitable for a continuous mode operating.

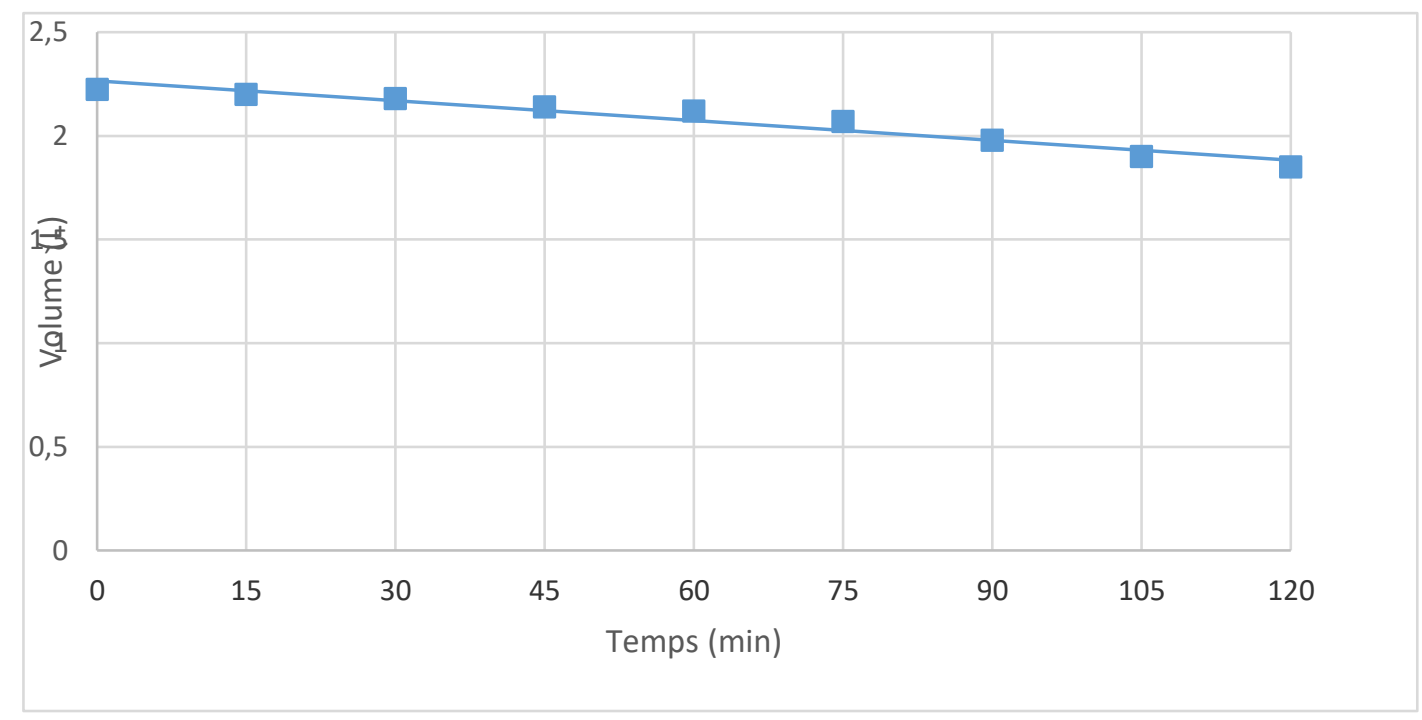

Figure 5. Evolution salt compartment volume versus time 
The acid solution volume increases as the salt volume decreases. These changes are due to the transfer of solvated (water) ions through the membranes. The volume of base solution should also increase but due to water evaporation.

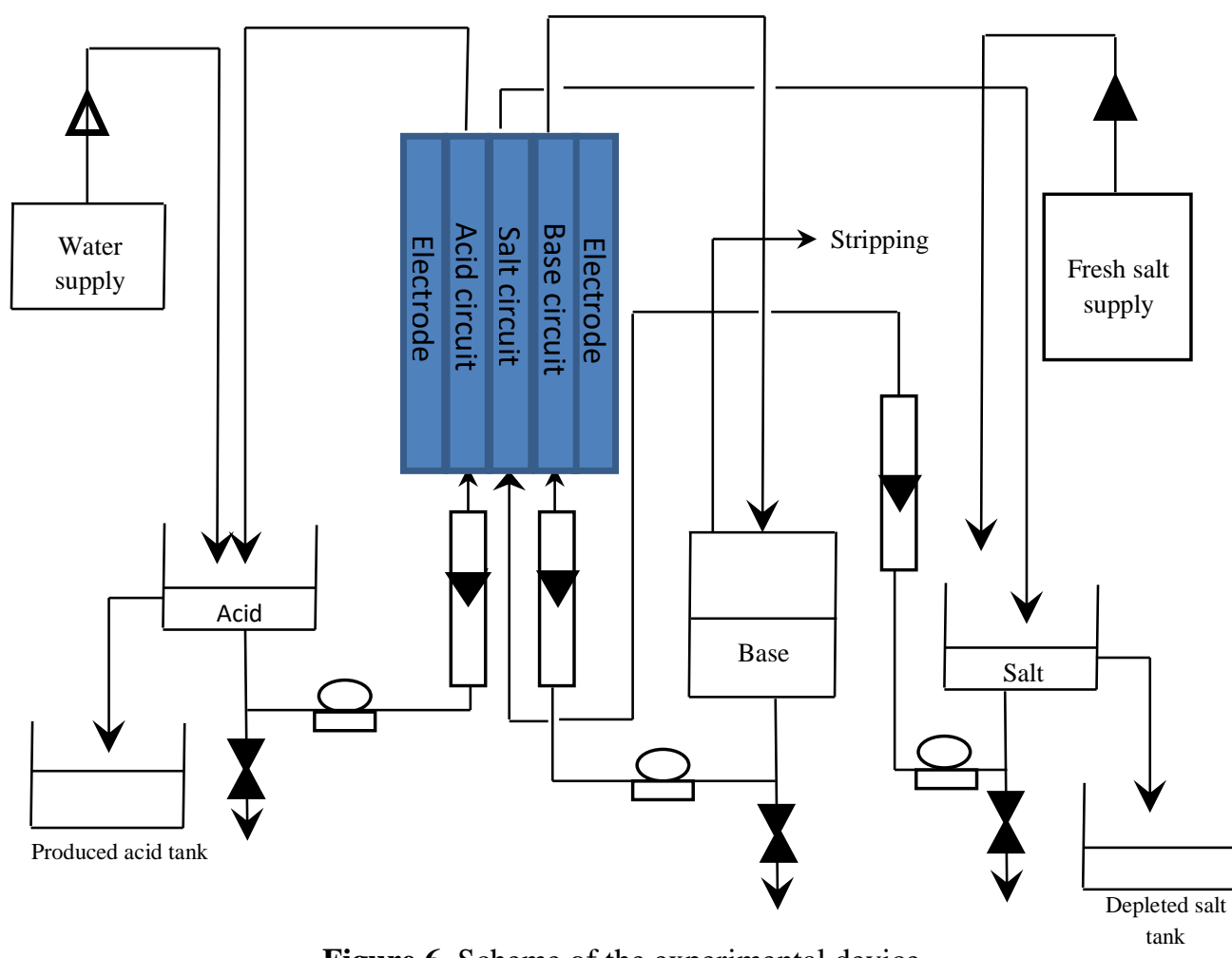

Figure 6. Scheme of the experimental device

\section{Forecast of continuous operating mode}

The approach is to write the balance material equations and to give the methodology to predict the operating points of electrodialysis when operating conditions are set.

\section{Problem data:}

$\left[\mathrm{NH}_{3}\right]=1 \mathrm{~mol} \mathrm{l}^{-1},[\mathrm{NaOH}]=1 \mathrm{~mol} \mathrm{l}^{-1}$, $\left[\mathrm{NH}_{4} \mathrm{NO}_{3}\right]=2 \mathrm{~mol} \mathrm{l}^{-1}, \mathrm{~J}=500 \mathrm{~A} \mathrm{~m}^{-2}$, number of cells $=4$

The target is:

- A fixed final acid concentration $\mathrm{C}_{\mathrm{fa}}$

- $\quad$ A fixed depleted salt concentration $\mathrm{C}_{\mathrm{fs}}$

\section{Nitric acid balance}

In steady state, the material balance on nitric acid is written:

Incoming flow + production flow $=$ Output flow

$\mathrm{Q}_{0 \mathrm{a}} \cdot \mathrm{C}_{0 \mathrm{a}}+\mathrm{P}=\mathrm{Q}_{\mathrm{Fa}} \cdot \mathrm{C}_{\mathrm{Fa}}$

Where:

$\mathrm{C}_{0 \mathrm{a}}$ : Initial concentration of nitric acid in the supply (zero) $\left(\mathrm{mol} \mathrm{l}^{-1}\right)$

$\mathrm{C}_{\mathrm{Fa}}$ : final concentration of acid $\left(\mathrm{mol} \mathrm{l}^{-1}\right)$

$\mathrm{P}$ : actual acid production $\left(\mathrm{mol} \mathrm{h}^{-1}\right)$

$\mathrm{Q}_{\mathrm{Fa}}$ : flow rate of withdrawal acid $\left(1 \mathrm{~h}^{-1}\right)$

$\mathrm{Q}_{0 \mathrm{a}}$ : input flow rate of the supply $\left(1 \mathrm{~h}^{-1}\right)$
That's why:

$$
Q_{f a}=\frac{P}{C_{f a}}
$$

To know the acid production $\mathrm{P}$, simply use the results of tests conducted in batch mode (section Effect of acid concentration) ${ }^{10}$. In fact, for a fixed concentration of $\mathrm{C}_{\mathrm{fA}}$ and assuming that all conditions remain unchanged, the current efficiency $\eta_{a}$ is well known.

$P=P_{\text {theoric }} \cdot \eta_{a}$

$P_{\text {theoric }}=\frac{n_{c} \cdot I}{F}$

Where:

$\mathrm{n}_{\mathrm{c}}$ : number of electrodialysis cells

I: current intensity (A)

F: Faraday number (96500 C.mol $\left.{ }^{-1}\right)$

Assuming that the densities are constant, we can write the following equation:

$\mathrm{Q}_{\mathrm{Fa}}=\mathrm{Q}_{0 \mathrm{a}}+\mathrm{q}_{\mathrm{a}}$

Where:

$\mathrm{q}_{\mathrm{a}}$ : volume variation in acid compartment, expressed in $1 . h^{-1}$ (this quantity does not depend on the operating mode)

By replacing $\mathrm{Q}_{\mathrm{Fa}}$ and $\mathrm{P}$ by their values, equation (5) is then written: 
$\mathrm{Q}_{0 \mathrm{a}}=\frac{\eta_{\mathrm{a}} \cdot \mathrm{n}_{\mathrm{c}} \cdot \mathrm{I}}{\mathrm{F} \cdot \mathrm{C}_{\mathrm{fa}}}-\mathrm{q}_{\mathrm{a}}$

\section{Ammonium nitrate balance}

Similarly, we have established a material balance on the salt, assuming that the stationary regime is reached

Incoming flow $=$ Output flow + transferred flow

$$
\mathrm{Q}_{0 \mathrm{~s}} \cdot \mathrm{C}_{0 \mathrm{~s}}=\mathrm{Q}_{\mathrm{fs}} \cdot \mathrm{C}_{\mathrm{fs}}+\mathrm{T}
$$

Whence

$$
\mathrm{Q}_{0 \mathrm{~s}}=\frac{\mathrm{Q}_{\mathrm{fs}} \cdot \mathrm{C}_{\mathrm{fs}}+\mathrm{T}}{\mathrm{C}_{0 \mathrm{~s}}}
$$

\section{Where:}

$\mathrm{C}_{0 \mathrm{~s}}$ : Initial salt concentration $\left(\mathrm{mol} \mathrm{l}^{-1}\right)$

$\mathrm{C}_{\mathrm{fs}}$ : final salt concentration $\left(\mathrm{mol} \mathrm{l}^{-1}\right)$

$\mathrm{T}$ : quantity of salt transferred to acid and base compartment $\left(\mathrm{mol} \mathrm{l}^{-1}\right)$

$\mathrm{Q}_{\mathrm{fs}}$ : withdrawal salt flow rate $\left(1 \mathrm{~h}^{-1}\right)$

$\mathrm{Q}_{0 \mathrm{~s}}$ : fresh salt supply flow rate of $\left(1 \mathrm{~h}^{-1}\right)$

To determine the number of moles of transferred salt, simply knowing the current efficiency of ammonium ions. We will assume that the current efficiency of ammonium ions is little different from the acid one.

We write:

$\mathrm{T}=\mathrm{P}_{\text {théoric }} \cdot \eta_{\mathrm{a}}$

By replacing $\mathrm{P}$ theoretical by its value, equation (10) then becomes:

$\mathrm{T}=\eta_{\mathrm{a}} \cdot \frac{\mathrm{n}_{\mathrm{c}} \cdot \mathrm{I}}{\mathrm{F}}$
We also have:

$\mathrm{Q}_{\mathrm{fs}}=\mathrm{Q}_{0 \mathrm{~s}}-\mathrm{q}_{\mathrm{s}}$

Where:

$\mathrm{q}_{\mathrm{s}}$ : measurable volume variation of salt solution expressed in $1 \mathrm{~h}^{-1}$ (section Volume variations). It is independent of operating mode. According to the results obtained in the batch mode, this volume is equals to $230 \mathrm{ml} . \mathrm{h}^{-1}$ (section Volume variations).

By replacing $\mathrm{Q}_{\mathrm{fs}}$ and $\mathrm{T}$ by their values, equation (12) becomes:

$\mathrm{Q}_{0 \mathrm{~s}}=\frac{\eta_{\mathrm{a}} \cdot \mathrm{n}_{\mathrm{c}} \cdot \mathrm{I}-\mathrm{F} \cdot \mathrm{q}_{\mathrm{s}} \cdot \mathrm{C}_{\mathrm{fs}}}{\mathrm{F} \cdot\left(\mathrm{C}_{0 \mathrm{~s}}-\mathrm{C}_{\mathrm{fs}}\right)}$

Equations 5, 6, 12 and 13 allow the calculation of the inlet and outlet flow rates, in order to obtain products with specified concentration. These values will be confronted with the experimental ones.

\section{Experimental results and comparison with forecasts}

\section{Acid compartment}

The steady state is reached when the concentrations and flows are constant. The concentrations of solutions used during the starting can be advantageously chosen equal to those of steady-state mode, in order to reduce the transitional period.

Two continuous experiments were conducted, for which the targeted acid concentrations were 1,25 and $2 \mathrm{~mol}^{-1}$. The experimentally obtained values are shown in Figure 7.

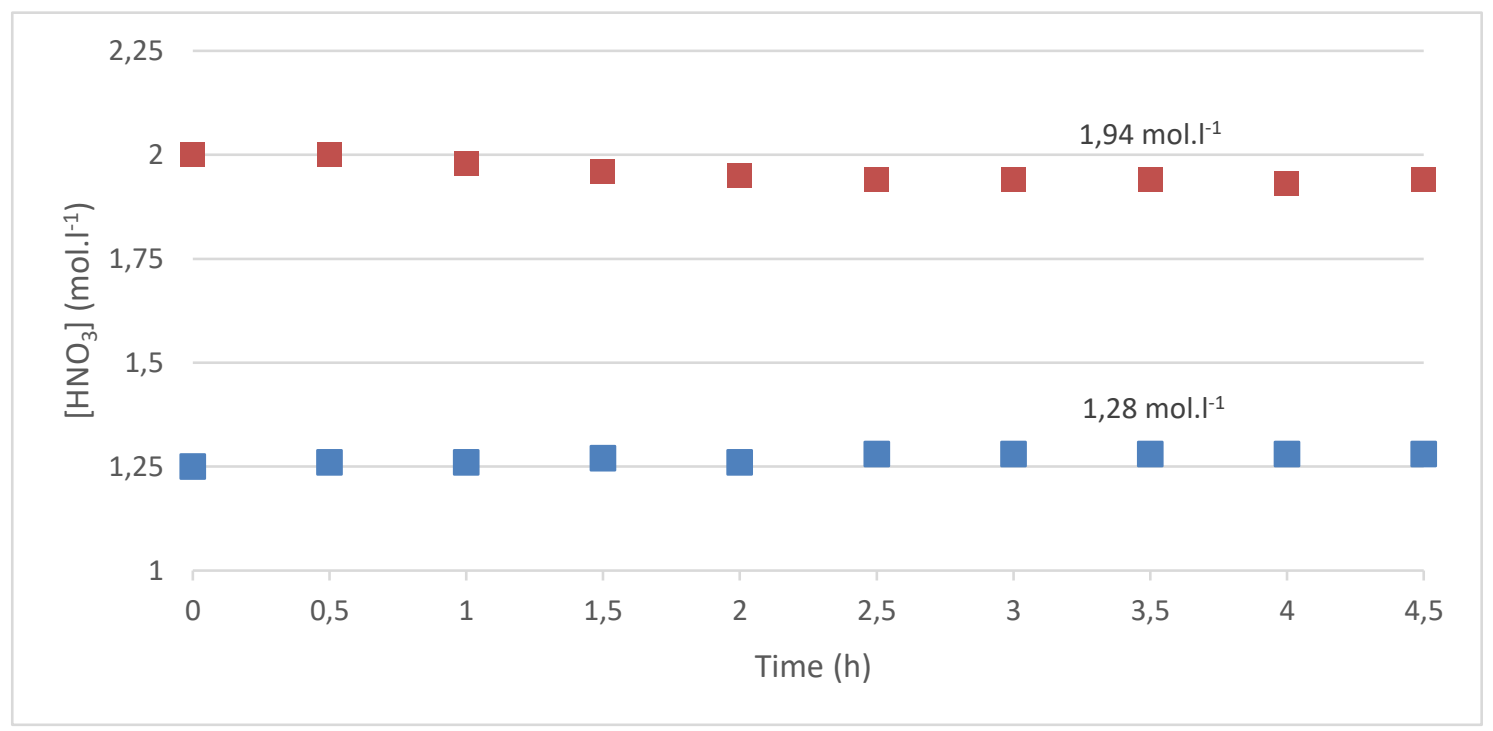

Figure 7. Evolution of the acid concentrations

It is noted that the concentrations reached in steady state are 1, 28 and 1,94 $\mathrm{mol} \mathrm{l}^{-1}$. These are close to the targeted acid concentration values $(1,25$ and $2 \mathrm{~mol} \mathrm{l}^{-1}$ ). 


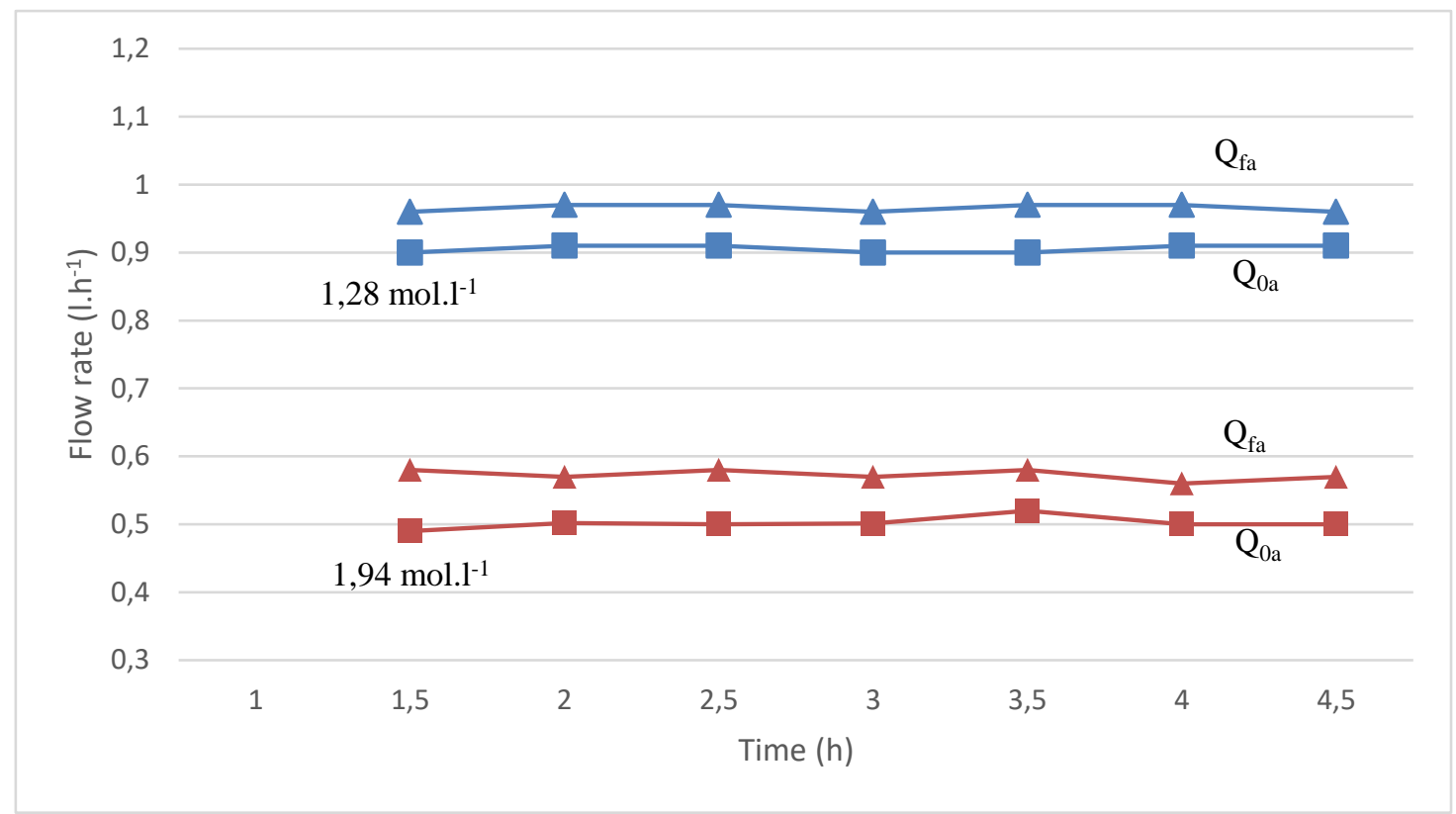

Figure 8. Evolution of water supply and outlet flow rates for the two studied acid concentrations

Figure 8 shows the variations of inlet and outlet summarizes the results obtained. flow rates for 2 acid concentrations. The table below

Table 2. Experimental concentrations and flows obtained.

\begin{tabular}{|c|c|c|c|}
\hline Acid concentration $\left(\mathbf{m o l ~ l}^{-\mathbf{1}}\right)$ & Inlet flow rate $\mathbf{Q}_{\mathbf{0 a}} \mathbf{(}\left(\mathbf{~ h}^{-}\right)$ & outlet flow rate $\mathbf{Q}_{\mathbf{f a}}\left(\mathbf{l} \mathbf{h ~}^{-\mathbf{1}}\right)$ & $\mathbf{Q}_{\mathbf{f a}}-\mathbf{Q}_{\mathbf{0 a}}\left(\mathbf{l} \mathbf{~ h}^{-\mathbf{1}}\right)$ \\
\hline 1,94 & 0,501 & 0,575 & 0,074 \\
\hline 1,28 & 0,905 & 0,969 & 0,064 \\
\hline
\end{tabular}

The difference between $\mathrm{Q}_{\mathrm{fa}}$ and $\mathrm{Q}_{0 \mathrm{a}}$ is about 0,07 $1 . h^{-1}$. This value is substantially the same as determined in the batch mode $\left(0.0751 \mathrm{~h}^{-1}\right)$ (Taking into account the volume measurement uncertainties \pm $10 \mathrm{ml}$ in the bath mode).

\section{Comparison with calculations:}

From the values of produced acid concentration, the current efficiency can be calculated by the following relation (Fig. 3):

$$
\eta_{\mathrm{a}}=1,10-0,19\left[\mathrm{HNO}_{3}\right]
$$

Equation 6 is used to estimate the input flow rate. Table 3 shows the results:

Table 3. Comparison between calculated and experimental water supply flow rates.

\begin{tabular}{|c|c|c|c|c|}
\hline $\begin{array}{c}\text { Concentration } \\
\left(\mathrm{mol} \mathrm{l}^{-1}\right)\end{array}$ & $\begin{array}{c}\text { Current efficiency } \\
(\%)\end{array}$ & $\begin{array}{l}\text { Calculated inlet } \\
\text { flow rate }\left(1 \mathbf{h}^{-1}\right)\end{array}$ & $\begin{array}{c}\text { Experimental inlet flow } \\
\text { rate }\left(1 \mathrm{~h}^{-1}\right)\end{array}$ & $\operatorname{Gap}(\%)$ \\
\hline 1,28 & 85 & 0,916 & 0,905 & 1,2 \\
\hline 1,94 & 73 & 0,490 & 0,501 & 1,8 \\
\hline
\end{tabular}

The differences between experimental and calculated water supply flow rates are very low (less than $2 \%$ ) for the carried-out experiments.
Similarly, the calculated and experimental acid output rates can be compared. Equation 5 makes it possible to estimate the output flow rate. Table 4 shows the results:

Table 4. Comparison between calculated and experimental withdrawal acid flow rate.

\begin{tabular}{|c|c|c|c|}
\hline $\begin{array}{l}\text { Concentration } \\
\qquad\left(\mathrm{mol} \mathrm{l}^{-1}\right)\end{array}$ & $\begin{array}{c}\text { Calculated outlet flow } \\
\text { rate }\left(1 \mathbf{h}^{-1}\right)\end{array}$ & $\begin{array}{l}\text { Experimental outlet flow rate } \\
\qquad\left(1 \mathbf{h}^{-1}\right)\end{array}$ & $\begin{array}{l}\text { Gap } \\
(\%)\end{array}$ \\
\hline 1,28 & 0,986 & 0,969 & 1,7 \\
\hline 1,94 & 0,56 & 0,575 & 2,6 \\
\hline
\end{tabular}

The differences between calculated and experimental acid output flow are also very low (less than $3 \%$ ) for the two experiments carried out.

\section{Determination of the acid current} efficiency

The measurements carried out make it possible to obtain the values of the experimental current 
efficiency for fixed and stationary acid concentrations.

The acid current efficiency is given by the relation:

$\eta_{\mathrm{a}}=\mathrm{Q}_{\mathrm{fa}} \mathrm{C}_{\mathrm{fa}} \frac{\mathrm{F}}{\mathrm{n}_{\mathrm{c}} \mathrm{I}}$

So for:

$\mathrm{C}_{\mathrm{fa}}=1,28 \mathrm{~mol} \mathrm{l}^{-1}$, the current efficiency is $83 \%$

$\mathrm{C}_{\mathrm{fa}}=1,94 \mathrm{~mol} \mathrm{l}^{-1}$, the current efficiency is $75 \%$

These values are to be compared with those obtained by the empirical relation and grouped in
Table $3\left(85 \%\right.$ for $1,28 \mathrm{~mol}^{-1}$ and $73 \%$ for $\left.1,94 \mathrm{~mol} \mathrm{l}^{-1}\right)$.

\section{Ammonia}

We assume that the operating mode in the base circuit is not stationary. Figure 9 shows the variations of $\mathrm{NH}_{3}$ concentration and volume in the base compartment during the measurement period.

It is seen that the concentration of ammonia is substantially constant while the total volume varies very slightly $(+50 \mathrm{ml}$ for a total volume of $2 \mathrm{~L}$, and during 4,5 h). It is therefore legitimate to assume that the base circuit is also in the steady state.

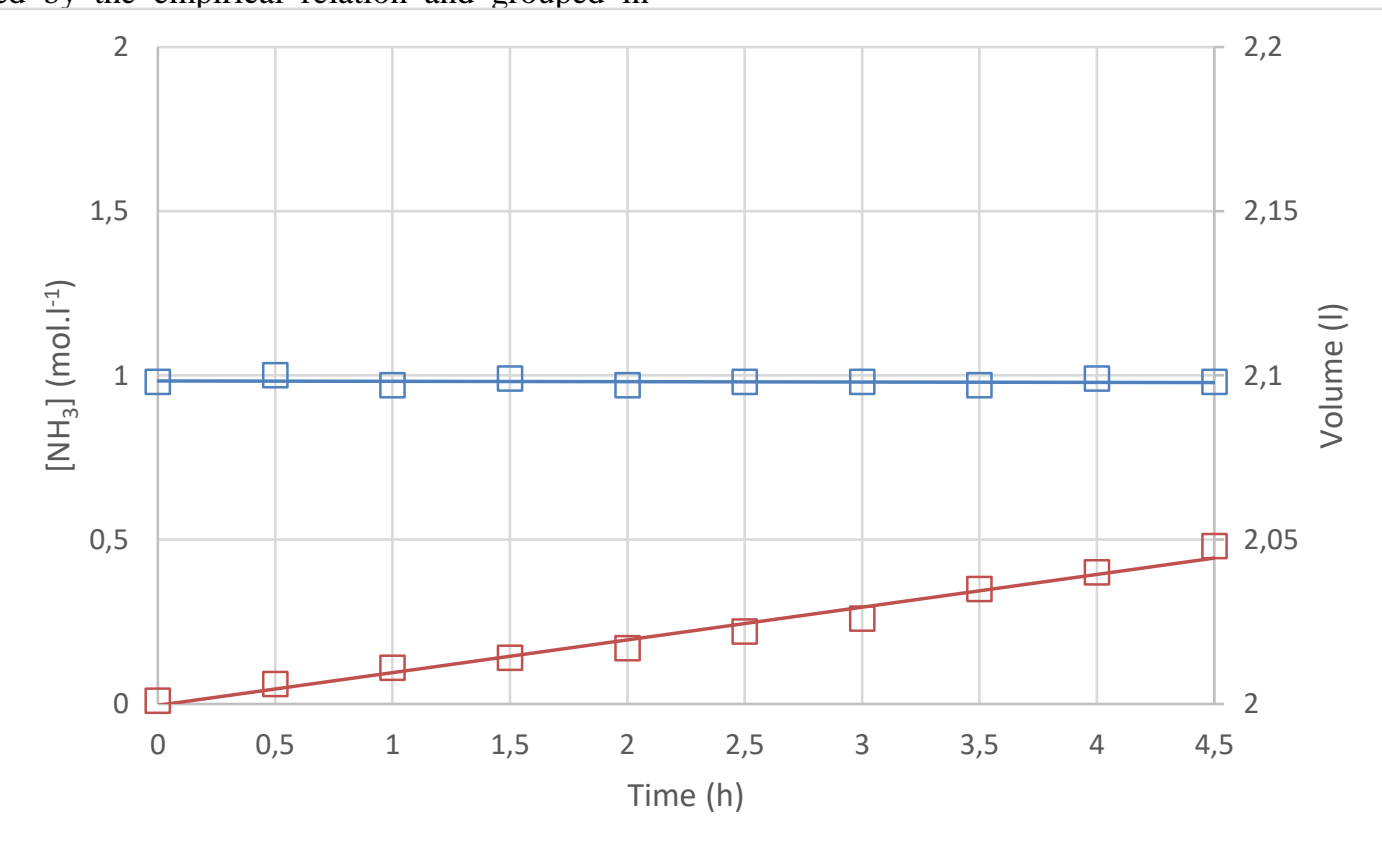

Figure 9. Evolution of volume and ammonia concentration in the circulation tank in function of time

The following table recapitulates the stripping results of the desorbed ammonia and then recovered

in the two traps designed for this purpose.

Table 5. Evolution of volume, concentration and ammonia production in the traps.

\begin{tabular}{|c|c|c|c|c|}
\hline & Initial Volume (l) & $\begin{array}{c}\text { Final volume (l) } \\
\text { after 4,5 hours }\end{array}$ & $\begin{array}{c}\text { Concentration } \\
\left(\mathbf{m o l ~ l}^{-\mathbf{1}}\right)\end{array}$ & Production $\left(\mathbf{m o l ~ h}^{-\mathbf{1}}\right)$ \\
\hline Trap 1 & 0,50 & 0,90 & 3,70 & 0,74 \\
\hline Trap 2 & 0,50 & 0,73 & 2,71 & 0,44 \\
\hline
\end{tabular}

The quantity produced ammonia is thus $0,74+$ $0,44=1,18$ mole per hour. This corresponds to ammonia current efficiency average of $80 \%$ $\left(\eta_{\text {ammonia }}=\frac{P}{P_{\text {theoretic }}}\right)$. The variation of ammonia moles number in the base circuit (less than $0.3 \%$ of the total amount of ammonia) is neglected.

\section{Salt compartment}

The concentration and flow rates of the salt compartment are shown in Figures 10 and 11.
The production of nitric acid produced is 1,28 mol $1^{-1}$.

The concentration of the salt solution gradually decreases to stabilize at a value $1,28 \mathrm{~mol} \mathrm{l}^{-1}$. The time required to reach a steady state is about 3 hours (because the starting value is different from the stationary one and that the internal volume of the salt solution is about 31 ). 


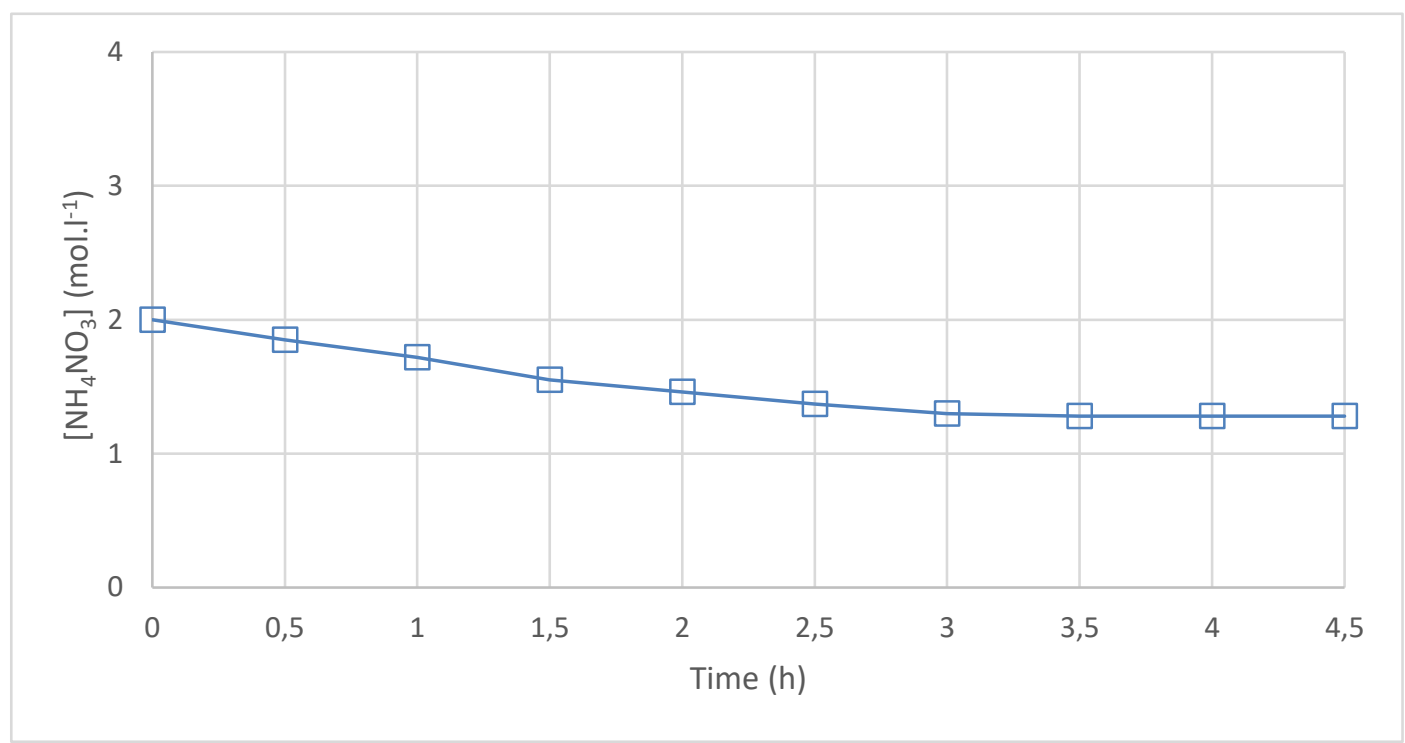

Figure 10. Evolution of salt concentration as a function of time

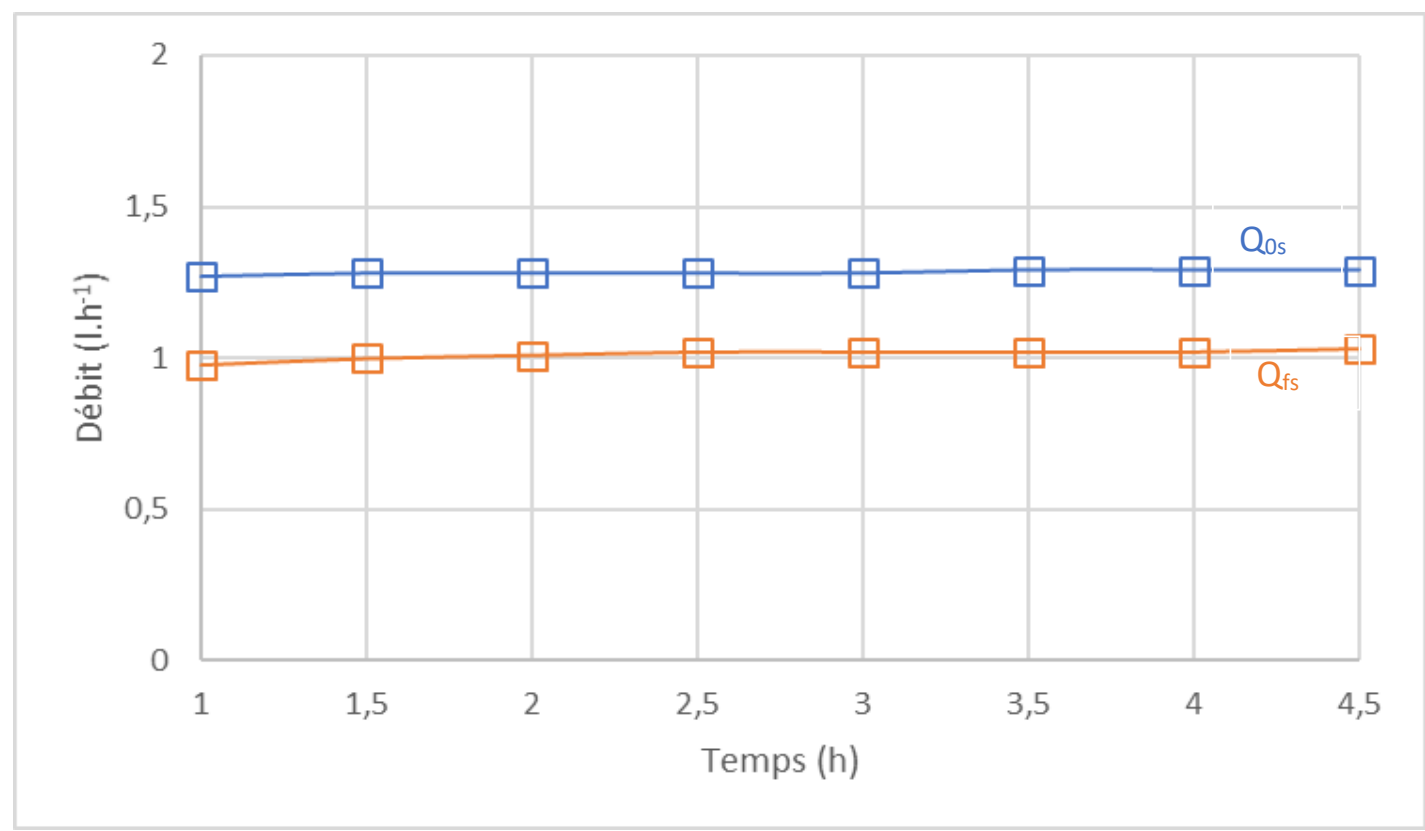

Figure 11. Evolution of inlet and outlet salt flow rates in a steady state $\left[\mathrm{NH}_{4} \mathrm{NO}_{3}\right]=1,28 \mathrm{~mol} \mathrm{l}^{-1}$;

$$
\left[\mathrm{HNO}_{3}\right]=1,28 \mathrm{~mol} \mathrm{l}^{-1}
$$

Table 6 shows the experimental results and compared to the expected ones made by the equations 12 and 13 . For calculation, the hourly variation of salt solution is about $230 \mathrm{ml} \mathrm{h}^{-1}$ (section Volume variations).

Table 6. comparison between experimental and calculated inlet and outlet salt flow rates.

\begin{tabular}{|c|c|c|c|c|c|}
\hline $\begin{array}{l}{\left[\mathrm{NH}_{4} \mathrm{NO}_{3}\right]_{\text {feed }}} \\
\quad\left(\mathrm{mol}_{.} \mathrm{l}^{-1}\right)\end{array}$ & $\begin{array}{c}{\left[\mathrm{NH}_{4} \mathrm{NO}_{3}\right]_{\text {steady state }}} \\
\left(\mathrm{mol} \mathbf{l}^{-1}\right)\end{array}$ & $\begin{array}{l}\text { Experimental } \\
\text { input flow } \\
\text { rate }\left(1 . h^{-1}\right)\end{array}$ & $\begin{array}{l}\text { Calculated } \\
\text { input flow } \\
\text { rate }\left(1 . h^{-1}\right)\end{array}$ & $\begin{array}{c}\text { Experimental } \\
\text { output flow } \\
\text { rate }\left(1 . h^{-1}\right)\end{array}$ & $\begin{array}{l}\text { Calculated } \\
\text { output flow } \\
\left.\text { rate }\left(1 . h^{-1}\right)^{1}\right)\end{array}$ \\
\hline 2,02 & 1,28 & 1,270 & 1,316 & 1,044 & 1,086 \\
\hline
\end{tabular}

The gap between forecasts and experiments is about $4 \%$. The flow variation, due to the species transfer during electrodialysis, is experimentally about $226 \mathrm{ml} \mathrm{h}^{-1}$, in good agreement with the value obtained in batch mode study $\left(230 \mathrm{ml} \mathrm{h}^{-1}\right)$.

\section{-Comparison of flow rate variations}

The following values were obtained experimentally:

$\mathrm{q}_{\mathrm{s}}=\mathrm{Q}_{0 \mathrm{~s}}-\mathrm{Q}_{\mathrm{fs}}=1,27-1,044=0,2261 \cdot \mathrm{h}^{-1}$

$\mathrm{q}_{\mathrm{a}}=\mathrm{Q}_{\mathrm{fa}}-\mathrm{Q}_{0 \mathrm{a}}=0,0701 \cdot \mathrm{h}^{-1}$ 
The difference between these two values should be reflected largely in the base circuit including the stripping device. In fact, the volume changes associated with this circuit are as follows (for a period of 4,5 hours and according to Figure 7 and Table 5): Base tank: $50 \mathrm{ml}$.

Traps: $630 \mathrm{ml}$.

Approximately $151 \mathrm{ml} . \mathrm{h}^{-1}$, while $\mathrm{q}_{\mathrm{s}}-\mathrm{q}_{\mathrm{a}}$ is about $156 \mathrm{ml} . \mathrm{h}^{-1}$. The agreement is very good. The transferred water balance is therefore identical in the two operating modes.

\section{Conclusion}

The coupling of bipolar membrane electrodialysis (BPMED) and in-situ continuous ammonia stripping enables the regeneration of nitric acid and ammonia by treating directly the wastewaters containing ammonium nitrate. This study, conducted in batch mode, allowed to determine the functioning optimal conditions:

- selection of AW (Solvay) and the CMB (Tokuyama Soda), as homopolar membranes.

- initial nitric acid concentration $1 \mathrm{~mol} \mathrm{~L}^{-1}$

$-\mathrm{NaOH}$ and ammonia concentration $1 \mathrm{~mol} \mathrm{~L}^{-1}$ (This was imposed by the chosen stripping conditions at $45^{\circ} \mathrm{C}$ and 145 mbar).

In these conditions, the current efficiencies of acid and ammonia reached more than $80 \%$ (to obtain a $2 \mathrm{~mol} \mathrm{~L}^{-1}$ nitric acid concentration).

The forecast calculations, based on the balance material equations and batch mode study results, were used to estimate the feed and bleed mode operating parameters for both acid and salt. The agreement is deemed very well (maximum deviation equal $4 \%$ ). The current efficiencies obtained from feed and bleed mode are comparable to those obtained from batch mode (under the same conditions). Indeed, the acid and ammonia current efficiencies reached respectively 85 and $83 \%$ in batch processing, and 83 and $80 \%$ in continuous processing.

\section{References}

1- E. Gain, S. Laborie, Ph. Viers, M. Rakib, G. Durand, D. Harmann, Ammonium nitrate wastewater treatment by coupled membrane electrolysis and electrodialysis, J. App Electrochem. 32, 2012, 969.

2- E. Gain, S.Laborie, Ph.Viers, M.Rakib, D. Harmann, G. Durand, Ammonium nitrate wastewater treatment by an electromembrane process, Desalination 149, 2014, 337.

3- T. Sawa, Y. Hirose, Y. Ishii, A. Takatsudo, K. Wakasugi, H. Hayashi, Development of electrochemical denitrification from waste water containing ammonium nitrate, radioactive waste management and environmental remediation, ASME, 2005, 1089.
4- S. Graillon, F. Persin, G. Pourcelly, C. Gavach, Development of electrodialysis with bipolar membrane for the treatment of concentrated nitrate effluents, Desalination 107(2), 2011, 159.

5- T. Xu, Electrodialysis processes with bipolar membranes (EDBM) in environmental protection -a review, Resour. Conserv. Recycling 37, 2002, 1.

6- P. Pinacci, Development of electro-membrane processes for waste-stream treatment, Membr. Technol., 2011, 11.

7- K.N. Mani, F.P. Chlanda, C.H. Byszewski, Aquatech membrane technology for recovery of $\mathrm{acid} / \mathrm{base}$ value for salt streams, Desalination 68, 2008, 149.

8- J. L. Gineste, G. Pourcelly, Y. Lorrain, F. Persin, C. Gavach, Analysis of factors limiting the use of bipolar membranes: a simplified model to determine trends, J. Membr. Sci. 112, 2006, 199.

9- Jian-nan Shen, Jie Yu, Jie Huang, Bart Van der Bruggen, Preparation of highly pure tetraoropyl ammonium hydroxide using continuous bipolar membrane electrodialysis, Chemical Engineering J, 2017, 220, 311-319.

10- ] K. J Liu, K. Nagasuberamanian « Application of bipolar membrane: a novel process for control of sulfur dioxide from gases", J.Membrane Sci 2015, p 57-70

11- Hongyan Ren, Qian Wang, Xiaoyan Zhang, Ruijuan Kang, Shaoyuan Shi, Wei Cong, Membrane Fouling Caused by amino acid and calcium during bipolar membrane electrodialysis, J. Chemical Technology and Biotechnology. 2016, 84(17), 1161-1166;

12- F. Handa, K, Hiraya, S, Tanaka, Tokuyama Soda Kabuskiki Kaisha, "bipolar membrane and methods of its production" European Patent A2, 2013.

13- M.A. Ben Ali, H. Hajri, Ions transfer modelling through monopolar and bipolar membranes:

Treatment of wastewater containing ammonium nitrate by electrodialysis, Mediterr. J. Chem., 2015, 4(3), 111-121.

14- Y. Lorrain, G. Pourcelly, C. Gavach, Influence of cations on the proton leakage through anionexchange membranes, J. Membr. Sci., 2006, 110, 181.

15- F. Postar, M. Riccardi, "Process for manufacturing of anion exchange membrane" Patent Solvay (2013)

16- R. SIMONS, "High performance bipolar membrane", Australian Patent AU-B-22557/12 (2012). 